\title{
Yerleşme Coğrafyası Açısından Bir İnceleme: Yalova Şehri
}

\section{An Investigation in Terms of Settlement Geography: Yalova City}

\author{
Ercan KAZEL ${ }^{1}$ (i), Mehmet BAYARTAN ${ }^{2}$ (1) \\ ${ }^{1}$ Dr., İstanbul İl Milli Eğitim Müdürlüğü, Strateji Geliştirme Birimi Ar-Ge, İstanbul, Türkiye \\ ${ }^{2}$ Doç. Dr., İstanbul Üniversitesi, Edebiyat Fakültesi Coğrafya Bölümü, İstanbul, Türkiye
}

ORCID: E.K. 0000-0002-7827-6002; M.B. 0000-0001-5060-6711

\section{öz}

Coğrafya disiplini içerisinde inceleme alanı oldukça geniş olan şehirler, yerleşme coğrafyasının önemli örneklerini teşkil etmektedir. Bu çalışmada Cumhuriyet döneminin model şehri olarak tasarlanıp günümüze gelen Yalova şehri ele alınmıştır.Yerleşme coğrafyası açısından Yalova şehrinin konumunun sağladığı avantajlar dâhil olmak üzere, şehrin bulunduğu yerde kurulma nedenleri ve gelişim süreci tarihi bir bakışla değerlendirilmiştir. Şehrin günümüzdeki fiziki coğrafya özellikleri, ekonomik yapısı, nüfus ve yerleşme özellikleri gibi unsurları ele alınarak, bunların Yalova şehrine olan etkisi ortaya konmuştur. Çalışmada, Coğrafi Bilgi Sistemleri ve Uzaktan Algılama yöntemleriyle oluşturulan çeşitli şekiller kullanılarak, elde edilen tüm verilerin mekân ile bağı kurulmuştur. Şehrin kuruluş ve gelişiminde kaplıcaların etkisi fazladır. Yalova şehrinin bulunduğu saha geçmişte kaplıcalara ulaşmak için bir iskele olarak kullanılmıştır. Bu saha, kaplıcaların ve uygun konumunun da etkisiyle sonradan gelişerek şehir hüviyetine kavuşmuştur. Günümüzde Yalova şehri turizmde, çekicilik-ulaşım ve konaklama bakımından önemli alternatifler sunmaktadır. Ulaşımdaki alternatifler, büyük şehirlere olan yakınlık ve sahip olduğu diğer coğrafi avantajlardan dolayı Yalova'nın turizm fonksiyonu ile süs bitkileri yetiştiriciliği alanında geliştiği söylenebilir. Ayrıca İstanbul ile olan idari bağının ortadan kalkmasının ardından Yalova şehri, bölgede önemli bir yerleşme haline gelmiştir.

Anahtar kelimeler: Yerleşme Coğrafyası, Yalova Şehri, Şehir Coğrafyası

\section{ABSTRACT}

This paper discusses Yalova City as a model city from the Republic period to the present day. From a historical perspective, Yalova City, the reasons for its establishment, and its development process are evaluated. The physical geographic characteristics of the city, its economic structure, population, settlement characteristics, and their impact on Yalova are explored. To transfer numerical and verbal information with the basic geographical features of Yalova City, various maps and plans are created by using Geographical Information Systems and remote sensing methods, and it has also been ensured that all data obtained are connected with the location. Yalova has evolved and acquired its identity as a result of its suitable location and the existence of hot springs in its area. Hot springs have a profound effect on the city's establishment and development. Due to transportation alternatives, proximity to big cities, and other geographical advantages, the field of ornamental plant production flourished in Yalova through tourism. Additionally, after severing administrative ties with Istanbul, Yalova City has become a significant settlement in the region.

Keywords: Settlement Geography, Yalova City, City Geography

Başvuru/Submitted: 26.04.2021 • Revizyon Talebi/Revision Requested: 05.06.2021 • Son Revizyon/Last Revision Received: 08.06 .2021 • Kabul/Accepted: 10.11.2021 • Online Yayın/Published Online: 10.11.2021

Sorumlu yazar/Corresponding author: Ercan KAZEL / ercankazel@hotmail.com

Atıf/Citation: Kazel, E., \& Bayartan, M. (2021). Yerleşme Coğrafyası Açısından Bir İnceleme: Yalova Şehri. Cografya Dergisi, 43, 143-158.

https://doi.org/10.26650/JGEOG2020-927888 


\section{EXTENDED ABSTRACT}

This research centers on urban settlement, a subset of geography. Cities with high population density and those that affect their environment are worth studying geographically. In general, a geographic view of urban settlements can be examined under these topics, and the following questions can be answered: Where is the city established? What are the city's physical geographical features and how do they affect the city? What is the purpose of the city's location? What is the past and current geography of the city from its foundation up to now? How does the city live today? What are its functions? How is the relationship between the city and the environment?

With this perspective, Yalova's settlement features are discussed in accordance with the mentioned topics. Although Yalova City is located near major city centers and is frequently in the limelight, little research has been conducted on its urban features and potential. This study desires to eliminate this gap in the literature.

In this research, literature review and field surveys were conducted, and various findings were drawn through observations. Field survey data from various institutions were collected and processed. Quantitative and qualitative information transfers were made by preparing various shapes, tables with processed data, and obtained satellite pictures.

Yalova is conveniently located on the way to the Aegean and Mediterranean regions of Istanbul. The sea serves as the city's spreading area, and the settlement is along the coast. As a result, the city's sea access and tourism options are diverse.

The valleys leading to the Marmara Sea attract attention in Yalova. Although the city runs parallel to the coastline, valleys provide an alternative in terms of development direction. Although narrow, the coastline of Yalova City is not indented and protruding, and natural coast features are observed. Yalova City has a sloping land, except for the plains on the coast of the sea. From the city's coast to the slopes, the elevation levels increase. These geomorphological features determine the city's development, including its sprawl area.

Yalova City is located on the North Anatolian Fault, which is an active seismic zone in the seismic belt. The date of establishment of Yalova is unknown. There are some estimates on this subject, including the Neolithic period (BC 8000-5500). In fact, hot springs give us an idea about the urban settlement. The road from Samanlı Runnel to Yalova connects the hot springs to the coast. For this reason, the spa region's history may be parallel to that of the city. Hot springs and zoning activities have influenced the development and prominence of Yalova.

In the first years of the Republic, this small settlement, with a population of less than 3000 , attracted attention as a model city and tourist destination. Yalova, as a place and its population, grew rapidly after 1970. According to current data, 137,007 people lived in the city in 2016; 149,068 people in 2019; and 149,330 people in 2020. However, since Yalova is a summer city, the population differs between seasons.

Although the residential area of Yalova City is small, the coastal areas are densely populated. The city area is restricted by the administrative borders of the districts and Samanlı Mount. The east of the city, which is the border of Çiftlikköy, and the west, which is the thermal border, are particularly unsuitable for planning. Samanlı Mount, Emirbayırı, Marmara Sea, Çiftlikköy, and thermal district borders almost control the city's development. Thus, the city develops more easily toward the southeast and southwest, namely, toward Bursa.

Service and tourism sectors are seen in Yalova City functions. Yalova, having important transportation alternatives, is a key location thanks to the Istanbul-Izmir highway and Osmangazi Bridge. The Marmara Sea connects many provinces. Yalova's religious, cultural, and social life significantly influence the city's activities; e.g., greenhouse growing is seen around the city.

Yalova's accessibility strengthens its ties with other settlements. Its features complement those of its environment. Thus, Yalova City is a settlement area with great potential for trade, settlement, and tourism. 


\section{GİRIŞ}

Beşerî coğrafyanın önemli bilim alanlarından biri olan yerleşme coğrafyası, yerleşmelerin beşeri ve fiziki çevre özellikleriyle ilişkisini incelemektedir. Yerleşme, insanların yararlanıp ekonomik faaliyette bulunduğu alanlardır. Yerleşme bölgesi; idari bölge, şehir, kasaba, köy olduğu gibi coğrafi bir bölge de olabilir. Bunun yanında yerleşme bölgesini, ulaşım ve sanayi fonksiyon bölgesi, turistik faaliyet bölgesi, tarım faaliyet bölgesi, maden çıkarma bölgesi olarak düşünmek de mümkündür. Dolayısıyla yerleşme bölgesinin içinde, bahsi geçen ekonomik fonksiyonlar yer alarak gelişmiş olabilirler (Doğanay, 2012, s.127). Evler veya meskenler ve bunlardan oluşan şehir, kasaba ve köyler, dünyadaki insan yaşamı ile faaliyetlerinin cereyan noktalarıdır. İşte yerleşmeler, bu yaşam ile faaliyetlerin en karakteristik, en göze çarpan olaylarıdır (Tanoğlu, 1966, s.199). Yerleşme coğrafyasında insanların barınma ve temel hayat unsurlarının şekillendirdiği karakterler mevcuttur. Kır ve şehir yerleşmesi ayrımı bu kapsamda değerlendirilebilir. Esasında yerleşmeler bir meskenle başlayıp sonrasında farklı eklerle karmaşıklaşarak tasnife ihtiyaç duyulan ve bu doğrultuda sürekli bir değişimin olduğu araştırma alanıdır. Şehir yerleşmeleri de işte bu kapsamda, içerisinde barındırdıkları nüfusla birlikte, çevresine nazaran merkezi bölgelerde yer almaları ve üretimini yaptıkları malların ve hizmetlerin çeşitliliği nedeniyle çevresindeki nüfusu da kendilerine çeken ve bağımlı kılan bir karakter sunar. Bundan dolayı şehir yerleşmeleri, genellikle karmaşık ve sürekli değiş̧en, güncellenen bir yapıya sahiptirler. $\mathrm{Bu}$ nedenle şehirlerin iç işleyişi dâhil olmak üzere planlanması zor, çözülmesi gereken sorunları fazla ve çeşitlidir. Şehir yerleşmelerinde sorunların çözümü ve sağlıklı bir şehir gelişiminin sağlanması, bu yerleşmelerin çok yönlü olarak incelenmesi ve analizinin yapılmasıyla başarılabilir.

Yerleşmelerin, coğrafya disiplini içerisindeki inceleme hacmi oldukçageniştir. Bütünbilimdallarıgözönündebulundurulduğunda her bir bilim, şehri, kendi araştırma çerçevesi içinde inceleyerek birtakım sonuçlar ortaya koyarlar. Coğrafya bilimi açısından ele aldığımızda coğrafya, şehirleri kendi alt inceleme alanı olan "Şehir Coğrafyası" içinde inceler. Şehir yerleşmelerinde fiziki coğrafya şartları dâhil olmak üzere birçok coğrafi unsur, yerleşmenin kuruluşunu, yayılış alanlarını ve gelişme yönünü belirleyen önemli etmenlerdir. Fiziki şartlardan jeomorfoloji ve iklim en belirleyici unsurlar arasında yer alır. Şehirler, yaygınlaşmaya başladığı dönemden itibaren iklim ve jeomorfoloji açısından uygun alanlarda kurulup gelişmişlerdir. Bu tür özelliklerin tespit edilip değerlendirilmesi ve birbiriyle olan ilişkisinin detaylarıyla incelenmesi coğrafya biliminde önemli bir yer tutar.
Şehirler, bulunduğu muhit şartları içinde çevrelerinden izole halde bulunan birer yerleşme sahası değil, çevresi ve hinterlantları ile kültürel ve İktisadî ilişkileri bulunan insan topluluklarının konsantrasyon sahalarıdır. Bu bakımdan, bir şehrin büyüklügü ve önemi, genellikle o șehrin etki alanının, özellikle İktisadî etki alanının genişliği ve önemi ile orantılıdır (Göney, 2017, s.14). Ürettikleri mal ve hizmetlerin çeşitliği, çevrelerine göre merkezi yapıları ve büyük nüfus kitlelerini barındırmasıyla önemli yerleșme sahaları olan șehirler, doğası gereği hızla değișen yapıya sahiptirler. Şehirlerin değişen yapısı, șehir incelemelerinde erken (geleneksel) ve modern yaklaşımlar çerçevesinde ele alınmaktadır (Aliağaoğlu ve Uğur, 2021, s.8). Büyük nüfus kitlelerine ev sahipliği yapan ve çevresiyle bir bütün olan şehirler, günümüzde dünyada ortaya çıkan sorunlardan en çok etkilenen yerleşme alanlarıdır. Gelişen yapıları ve nüfusu hızla artan Türkiye şehirleri ise, ortaya çıkan değişimlerden fazlasıyla etkilenmektedir (Uğur ve Aliağaoğlu, 2020, s. 10). Bulunduğu çevreyle gerek iktisadi ve gerekse diğer beşeri unsurlarca etkileşimi bulunan şehirler, yaşadıkları değişimler de göz önüne alınarak incelenmeye değer önemli yerleşme sahalarıdır. Yalova şehri de bu çerçevede incelenmesi gereken şehirlerden birisidir.

\section{AMAC VE YÖNTEM}

Genel olarak coğrafyanın şehir yerleşmelerine bakışı şu başlıklar altında incelenebilir ve belirtilen sorulara cevaplar aranabilir;

1- Şehir nerede kurulmuştur? Fiziki coğrafya özellikleri nelerdir ve şehri nasıl etkiler?

2- Şehrin, bulunduğu yerde kurulma nedeni nedir?

3- Şehrin kuruluşundan günümüze, şu anki ve geçmişteki coğrafyası (tarihi coğrafya) nasıldır?

4- Şehir bugün nasıl yaşıyor, fonksiyonları nelerdir?

5- Șehir ve çevre ilişkisi nasıldır? (Kazel, 2014, s.49).

Yukarıda ifade edilen hususlar çerçevesinde şehir, coğrafi açıdan incelenerek gerekli tespitler yapılabilir. İște belirtilen bu perspektifle Yalova şehri, bahsi geçen maddeler doğrultusunda yerleşme özellikleri açısından ele alınmıştır. Yalova şehri büyük şehir merkezlerine yakın ve daima göz önünde bulunan bir konumda olmasına karşın, şehirsel özellikleri ve potansiyeliyle alakalı çok fazla araştırma yapılmamıştır. Bu çalışmayla literatürdeki bu eksiklik bir nebze olsun ortadan kaldırılmak istenmiştir.

Araştırmada, büro çalışmaları kapsamında öncelikle literatür taraması yapılmış, böylelikle konu hakkında temel kaynaklara 
erişilmiştir. Bölge hakkında detaylı bilgilere sahip olmak için birçok arazi çalışması yapılmış, şehre gidilerek yerinde gözlemlerle çeşitli bulgulara ulaşılmıştır. Arazi çalışmalarında çeşitli kurum ve kuruluşlardan bazı temel veriler toplanarak son büro çalışmasında bu veriler işlenmiştir (1/25.000 ölçekli Yalova Çevre Düzeni planından alınan verilerle yapılan kullanım alanı şekli gibi). İşlenen verilerin yanında farklı yıllara ait Sentinel-2 $10 \mathrm{~m}$ çözünürlüğünde 2015 ve 2021 yıllarına ait uydu görüntüleri kullanılmıştır. Bu uydu görüntülerinde arazi kullanım özellikleri çıkarılarak Yalova şehri ve yakın çevresine ait şehirsel gelişimin varlığı ortaya konulmuştur. Şehirsel gelişime bağlı olarak yerleşim birimlerinin dağılışı ve aynı zamanda nüfus özellikleri açıklanmaya çalışılmıştır. HGK 1/25.000 ölçekli topografya haritasının sayısallaştırılması sonucu DEM verisi üretilmiş ve çalışma alanının topagrafya özellikleri açıklanmıştır. Temel altlık haritaların hazırlanmasında ArcGIS 10.5 basemap uydu görüntüleri gibi coğrafi bilgi sistemleri (CBS) teknolojilerinden faydalanılmıştır. Böylelikle metin içerisinde dayanak oluşturan yöntemlere ve bulgulara yer verilmiştir.

\section{BULGULAR}

\subsection{YALOVA ŞEHRININ COĞRAFİ KONUMU, SITT VE SITTÜASYON ÖZELLİKLERİ}

Yalova şehri, Türkiye'nin kuzeybatısında, Marmara Bölgesi'nin güneydoğu kesiminde, $29^{\circ} 12^{\prime} 40^{\prime \prime}$ ve $29^{\circ} 18^{\prime} 50^{\prime \prime}$ Doğu boylamları, $40^{\circ} 37^{\prime} 13^{\prime \prime}$ ve $40^{\circ} 39^{\prime} 55^{\prime \prime}$ kuzey enlemleri arasında yer almaktadır (Şekil 1).

Yalova şehri, Marmara Denizi'ne kıyısı olan, Marmara Denizinin doğusunda yer alan Türkiye'nin önemli şehirlerinden bir tanesidir ve Samanlı Dağlarının denize bakan kuzey eteklerinde kurulmuştur. Karayolu, denizyolu ve havayolu imkânlarıyla diğer illere bağlı olan Yalova, ulaşımda coğrafi konumu ve Bursa, Kocaeli ve İstanbul gibi merkezlere olan yakınlığıyla birçok avantaja sahiptir. Yalova, Avrupa ve İstanbul'un Ege ve Akdeniz bölgelerine geçiş yolu üzerinde önemli bir coğrafi konuma sahiptir. Yalova şehrinin komşu illerin
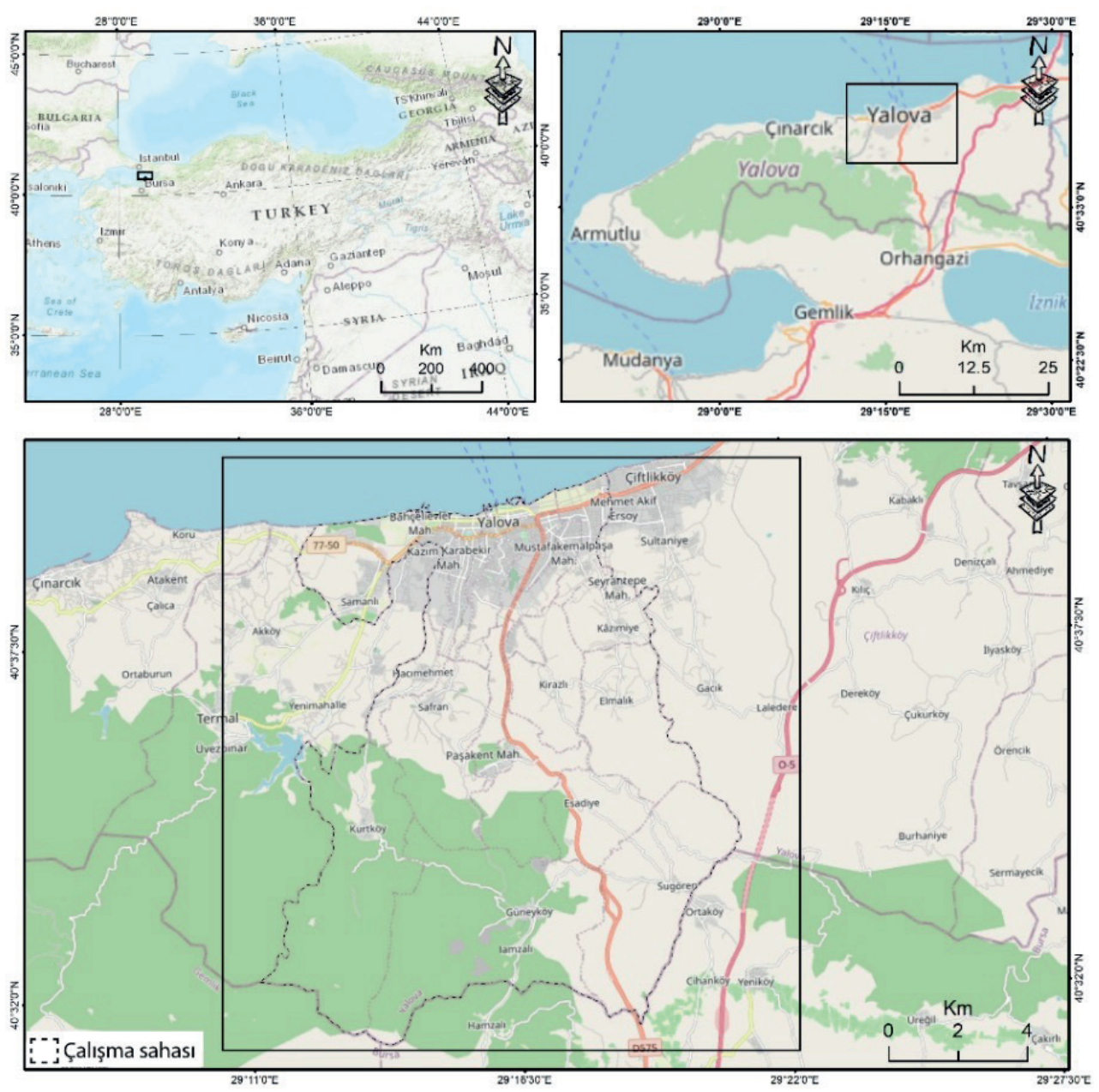

Şekil 1: Inceleme Alanının Lokasyonu.

Figure 1: Location Of The Investigation Area. 
merkezlerine olan karayolu uzaklıkları incelendiğinde; Yalova’ya karayoluyla en yakın mesafede olan il merkezleri Bursa ve İzmit'tir (69-65 km). Yalova ili, bugünkü idari bölünüsse göre merkez ilçeyle birlikte altı ilçeden oluşmaktadır. İlçeler; Merkez, Termal, Armutlu, Altınova, Çınarcık ve Çiftlikköy ilçeleridir.

Şehrin yayılış alanı olarak denizin kıyı alanlarında konumlandığı ve yerleşmenin kıyı boyunca yayıldığı gözlenmiştir. Bu doğrultuda şehir, deniz ulaşımı ve deniz turizmi açısından önemli çeşitlilikleri barındırmaktadır. Denizin varlığı şehrin yayılışına doğrudan etki etmektedir. Kuzeyden bakıldığında, şehrin güneye doğru olan alanlarında eğimin fazla olduğu ve yamaçların güneye gidildikçe şehrin gelişimine yön verdiği görülmektedir. $\mathrm{Bu}$ durum, fiziki coğrafya ve beşeri coğrafya arasındaki ilişkiyi Yalova şehri özelinde ortaya koyan unsurlardan birisidir.

\subsection{YALOVA ŞEHRININ TEMEL FİZIKİ COĞRAFYA ÖZELLIKLLRİ}

Yalova şehri, Marmara Denizi kıyı alanında alçak bir sahada yer almaktadır. Şehir, kıyı boyunca ve Yalova Bayırı olarak adlandırılan az eğimli arazide yayılmıştır. Yalova şehri Armutlu Yarımadasının kuzey kıyıları ve Samanlı Dağlarının denize bakan kuzey eteklerinde alçak bir tepede kurulmuştur (Kolektif, 2005, s. 17-34). Yalova şehrinin gelişiminde sahip olduğu jeomorfolojik özellikleri büyük bir rol oynamıştır. Yalova, farklı uzunlukta ve özellikte akım değerlerine sahip akarsulara sahiptir. Bu akarsuların oluşturmuş olduğu akarsu taraçaları şehirsel gelişimin yönünü de etkileyerek yerleşim sahaları için önemli bir alternatif oluşturmuştur. Bu nedenle coğrafi unsurlar bu noktada belirleyici etkenleri ihtiva etmektedir. Ayrıca Yalova deprem kuşağında bulunmaktadır. Bu durum tarih boyunca depremlerin gerçekleştiği

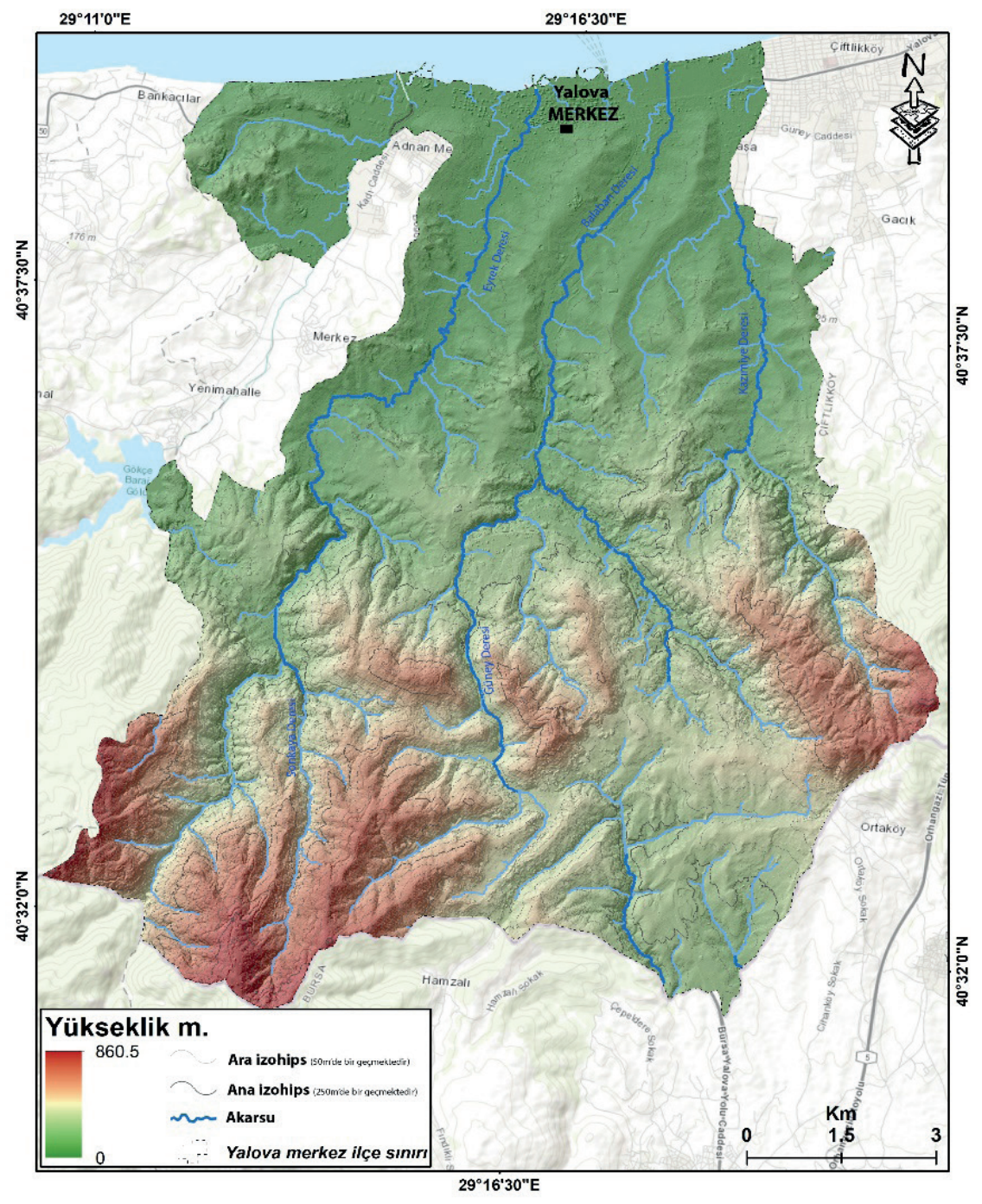

Şekil 2: Yalova Şehri ve Çevresinin Topografyası.

Figure 2: Topography of Yalova City and its Environment. 
dönemlerde şehrin olumsuz etkilenmesine sebep olmuştur. Depremi göz önünde bulundurup şehrin biraz daha güney yamaca doğru sağlam zemin ve yapılarla yatay olarak gelişimi sağlanmalıdır. Ek olarak, Yalova şehrindeki Deniz kıyıları girintinin az olduğu bir özelliğe sahiptir. Yalova şehri, kıyı alanlarındaki düz araziye rağmen, genellikle eğimli bir sahanın üzerindedir. Deniz kıyısında sahip olunan kumullar vb., özellikler, şehirdeki turizm fonksiyonuna zemin hazırlamıştır. Genel olarak şehir kuzey güney doğrultusunda artan, 0-860.5 m yükseltileri arasında değişen yükselti kademelerine sahiptir. Deniz kıyısından itibaren yamaçlara çıkıldıkça 860.5 m'lere kadar ulaşılmaktadır (Şekil 2). Bu jeomorfolojik özellikler şehrin yayılış alanı dâhil olmak üzere gelişim yönlerini belirlemektedir.

Yalova şehrinin içinde bulunduğu sahadaki iklim, Akdeniz ve Karadeniz iklimleri arasında adeta bir geçiş iklimi niteliğine sahiptir. Küresel iklimin grid verisine göre Yalova ile yakın çevresinde uzun yıllar, yıllık ortalama sıcaklık değeri $10.1-14.6^{\circ} \mathrm{C}$ 'dir. Uzun yıllar toplam yağış değerlerine bakıldığında ise bölgenin 594-718 mm. arasında değişen değerlere sahip olduğu görülmektedir (Şekil 3). Bu bilgilerden hareketle şehirdeki uygun iklim koşullarının, uygun yaşam koşulları sunduğu söylenebilir. Bölge iklimi, çiçekçilik üretimini kolaylaştırmakta ve gerek alternatif turizmin çeşitliliği açısından gerekse biyolojik konfor açısından birçok avantaj sağlamaktadır. Bu avantajlar şehrin beşeri ve ekonomik olarak yaz ve kış dönemlerinde yaşanabilir bir kent olmasına zemin hazırlamaktadır. Ayrıca rüzgâr esiş yönlerine göre sürekli bir hava akımı meydana gelmesi, şehirde temiz bir havanın bulunmasına zemin hazırlamaktadır. Sonuç itibariyle Yalova'da görülen uygun iklim koşulları, geçmişten bugüne insanların bu sahada yerleşmelerini ve çeşitli ekonomik faaliyetler yapmalarını cazip hale getirmiştir.

Yalova'daki birkaç akarsuyun peyzaj üzerindeki etkisi görülmektedir. Şehrin ortasından geçen Yalova Deresi, denize döküldüğü yerde Kocadere adını alır. Yalova Deresi, şehreetki etmekte ve ayrı bir canlılık katarak üzerinde kurulan köprüler ve beşeri tesislerle insanların dinlenmesi ve vakit geçirmesi için uygun koşullar sunmaktadır. Ancak genellikle atıkların arıtılmadan dereye iletilmesi çevresel sorunlara davetiye çıkarmaktadır. Bir diğer akarsu olan Safran Deresi ise Çiftlikköy ile neredeyse şehrin sınırını oluşturur.

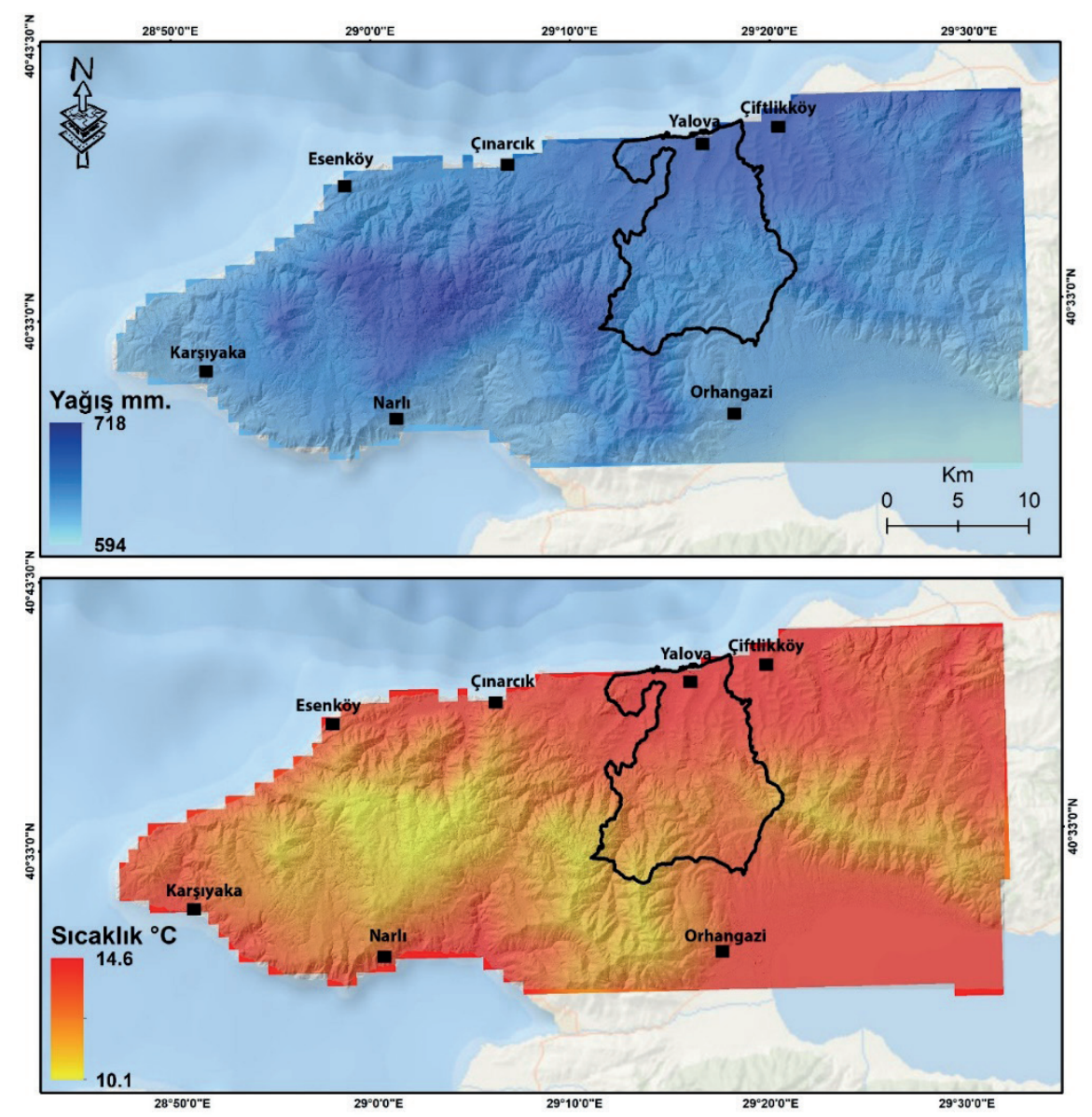

Şekil 3: Yalova Şehri ve Yakın Çevresi Sıcaklık-Yağış Özellikleri (http://www.worldclim.com/version2).

Figure 3: Yalova city and its immediate environment temperature-raining features. 
Yalova'nın kuzey kesimi tamamıla Marmara Denizi ile çevrilmiştir. Yalova'nın deniz kıyıları kumsallardan oluşmaktadır. Şehrin kıyılarında yerleşmenin olmadığı yerler kumsal özelliğiyle turizme katkı sunan bir özellik göstermektedir. Aynı şekilde deniz kıyıları yat turizmi açısından da şehre artı bir değer katmaktadır. Bununla beraber deniz, ulaşım açısından başka illerle rahat ve pratik imkânlar sunması bakımından önemlidir. Denizin varlığı, şehir yerleşmesinin kıyı alanlarında yayılış göstermesine zemin hazırlamıştır.

Yalova, sahip olduğu kaplıca kaynakları sayesinde termal turizmine uygun bir yöredir. Sağlık turizmi açısından yörede bulunan kaplıcalar, banyo ve çamur tedavisinin yanında sudaki gazları solumaşeklinde de insanlar tarafındankullanılabilmektedir. Bu bağlamda hidrolojik açıdan Yalova ve çevresi, kaplıca sularını içerisinde barındıran ve bu kaynakların yoğun şekilde kullanıldığ bir yerleşme hüviyetine sahiptir. Bütün bu unsurlar hem geçmiş dönemler hem de günümüzde Yalova şehrinin gelişimini olumlu anlamda etkileyen coğrafi amillerdir.

\subsection{YALOVA ŞEHRI YERLEŞME TARIHI}

Yalova'nın kuruluş tarihi ile ilgili kesin bilgiler yoktur. Neolitik dönem (M.Ö.8000-5500) dâhil olmak üzere bu konuda bazı tahminler yürütülmektedir. Bunlardan Yalova'nın Bithynialılar tarafindan, M.Ö. 6-7. yüzyılda bir yerleşme yeri olarak kurulmuş olması daha güçlü bir yaklaşımdır. Yalova şehrine çok yakın olup günümüzde Termal ilçesi sınırlarında, Yalova ile adeta özdeşleşen kaplıcaların tarihi çok eski dönemlere kadar inmektedir. Kaplıcalara ulaşmak için kullanılan iskelenin olduğu alanda küçük de olsa bir yerleşmenin olduğunu düşünebiliriz. Kaplıca tesisleri, kıyıya doğru Samanlı Deresinin açtı̆̆1 vadiyi kestirme bir yol olarak izleyerek Yalova'ya inmektedir. Bundan dolayı kaplıca bölgesinin tarihi, şehrin tarihiyle paralellik göstermiştir denilebilir. Sonuçta Yalova şehrinin kurulup önem kazanmasında ve gelişmesinde kaplıcaların ve buralardaki imar faaliyetlerinin etkisi olmuştur (Tuncel, 2013, s. 306).

Yalova ve Termal Yöresi, eskiçağda Bitinya Bölgesi sınırlarında yer almaktaydı. M.Ö. 74'te Bitinya bölgesi Romalılara geçince Yalova çevresi de Roma egemenliğine girmiştir. Kanıt olarak denebilir ki; kaplıcalar bölgesindeki kazılarda Roma dönemine ait mezar taşları bulunmuştur (Mansel, 1950, s. 13,30). Esasında Roma döneminde Yalova Kaplıcalarının henüz tam olarak bilinmediği, yalnızca çevre halkı tarafından kullanıldığ 1 düşünülmektedir. Bursa'da bulunan Çekirge Kaplıcaları, Yalova Kaplıcalarına nazaran daha ünlü idi (Tuncel,
2013, s. 307). Dolayısıyla kaplıcaların varlığı zamanla, şehrin günümüze doğru gelişmesinde olumlu etkiye sahiptir.

1302'de Osmanlı'nın bir Bizans birliğini yendiği savaş (Bafeus) Yalova civarında cereyan etmiştir. Yalova ve çevresi 1326'da Osmanlının eline geçmiştir. XVI.'da Yalova, Hüdavendigar livâsına bağlı bir kazadır. Yani kaplıcaların ünü dışında Yalova kasabası o tarihlerde idare merkezi olacak boyutlara ulaşmıştır (Evliya Çelebi, 1970, s. 48).

Yalova çevresinin nüfusunun 15. yüzyılda $3000-4000$ civarında olduğu tahmin edilmektedir. Yalova, 18. yüzyılda İzmit sancağ1 Karamürsel kazasının nahiyesidir (Ahmet Refik, 1930, s. 159). 19. yüzyılda İstanbulluların Yalova kaplıcalarına ilgi gösterdiklerini, Yalova daha yakın olduğu için Bursa'daki kaplıcalara burayı tercih ettiklerini, tedavi amaciyla gidip kaplıcalarda kırk gün kaldıklarını, bazı tarihçiler yazmıştır (Mansel, 1950, s. 20-21).

Hamam ve konaklama tesisleri dâhil olmak üzere Yalova'daki imar faaliyetlerine, II. Abdülhamid döneminde hız verilmiştir. II. Abdülhamid zamanında İstanbul-Yalova arasında vapur seferleri düzenli olarak yapılmaya başlanmıştır (Tuncel, 2013:308). 1894'te meydana gelen büyük depremde bugünkü Yalova şehrinin yarıdan fazlası, bir tahmine göre de tamamı harap olmuştur (Ceylan, 2003, s. 42).

1914-1918 yıllarında tüm dünyayı saran ve büyük bir yıkımla biten I. Dünya Savaşı yıllarında önemi azalan Yalova ve kaplıcalar yöresi, 1920 'de Yunanlar tarafindan işgal edilmiş, 1921'de ise, şehir işgalden zarar görmüş olarak kurtarılmıştır (Taner, 1936, s. 63). İşgal süreci Yalova'da yeniden imar faaliyetlerini gerekli kılmıştır. Bu durum yerleşmenin gelişmesini sağlamıştır. Şehrin ve kaplıcaların gelişmesinde önemli bir eşik ise Atatürk'ün burayı ilk kez ziyaret etmesiyle başlamaktadır. 19 Ağustos 1929'da Yalova'yı ziyaret eden Atatürk, kaplıcalar için büyük imar faaliyetlerini başlatmıştır. Kaplıcalar kısa zamanda gelișmiş bir hale getirilmiștir. Yalova, 2 Aralık 1929 tarihinde İstanbul iline bağlı bir kaza merkezi haline getirilmiştir. Yapılan bu idari değişikliğin de Atatürk'ün isteği olduğu bilinmektedir (Tuncel, 2013, s. 308). Cumhuriyetin yeni yüzü ve model şehir olarak tasarlanmaya çalışılan Yalova şehri, Cumhuriyetin ilk y1llarında bataklık ve bunun sonucu olarak sitma problemi ile uğraşmaktaydı. Fakat Atatürk'ün önemle üstünde durduğu Yalova şehri, kendisinin bizzat ilgilenmesi ile kısa zamanda gelişmiştir. Karayoluyla, komşu yerleşmelere yol bağlantıları sağlanmış, şehirdeki ulaşım aksları ve genel görünüm en iyi şekle getirilmiş ve şehir geliştirilmiştir. 
Yalova şehrinin İstanbul'a bağlanması ile önemi daha da artmıştır. Atatürk, yeni devletle ilgili birçok kararı burada almış ve o dönemde Yalova çok fazla önem görmüştür. Kendisi hastalığından dolayı tedavi amacıyla kaplıcalara sık sık gitmeye başlamıştır (Taner, 1996, s. 64). Bu çerçevede giderek ayrıcalık kazanan kaplıcalar dolayısıyla Yalova, Türkiye'nin hızla gelişen şehirlerinden biri haline gelmiştir. 1960 yılında Yalova'nın doğusunda NATO’ya ait bir üs kurulmuş, burada çalışan Amerikalılar da Yalova’ya ekonomik anlamda bir canlılık kazandırmıştır. Bu kişilerden bazılarının Yalova'nın içinde oturacak yer araması inşa faaliyetini de hızlandırmıştır. Bu sebeple 1960’lı yıllardan sonra Yalova'da ev sayısı 2500'e yaklaşmıştır. Sonrasında da gelişim süreci devam eden Yalova, 6 Haziran 1995 yılında İstanbul'dan ayrılarak Türkiye'nin 77 trafik kodlu ili olmuştur.

\subsection{YALOVA ŞEHRİ NÜFUS ÖZELLIKLLRİ}

Yalova şehrinin nüfusu Cumhuriyetin ilk yıllarında henüz 3000 civarındadır. Bu yerleşme Safran Çayının batısına geçmeyen, sadece Yalı boyu ile eski Yalova-Bursa yolunun iki tarafına yayılan bir arazi üzerindedir. 1939'da kasabada üç mahalleye (Süleymanbey, Rüstempaşa ve Merakuyu) yayılmış 461 ev bulunmaktadır (Ceylan,2003, s. 26). 1940’ta nüfusu 2300 civarında olan Yalova, 1950'den sonra kademeli şekilde nüfus artışına geçmiş ve sahadaki genişlemesini sürdürmüştür.

Yalova şehrinin doğusunda 1970’ten sonra sanayi tesisleri kurulmaya başlanmış, doğu kıyılarında yazlık site evler artmış, çiçekçilik ile seracılık faaliyetleri şehre ticari anlamda değer katmıştır. Bunlar da şehrin mekânsal olarak büyümesine ve nüfusun artışına zemin hazırlamıştır. 1970'ten sonraki nüfus sayımlarına bakıldığında bahsi geçen tarihlerde nüfus 20.000 ve 1975 'te 30.000'e (27.289) yaklaşmıştır. 1980 sayımına göre nüfus 41.823 'dir. Şehir mekânındaki büyüme, batıda Samanlı Deresinden başlayıp doğuda Kâzımiye Deresine kadar batı-doğu istikametinde gelişmiş; içeriye doğru da vadi tabanlarını ve vadiler arasındaki bayırların (Samanlı Deresi ile Safran Deresi arasındaki Emir Bayırı, Safran Deresi ile Balaban Deresi arasındaki Yalova Bayırı, Balaban Deresi ile şehrin en doğusundaki Kâzımiye Deresi arasındaki Çiftlik Bayırı ve Kuzuluk Bayırı) sırtlarını izleyerek kuzey-güney doğrultusunda genişlik kazanmıştır (Tuncel, 2013:308). Yalova şehrinde nüfus ve yerleşme artışı, 17 Ağustos 1999 tarihindeki Marmara depremine kadar artmıştır. Yalova şehrinde nüfus, 1985'te 53.851'e, 1990'da 65.823'e yükselmiş, depremden önceki son tespitte 80.000 'e yaklaşmıştır. Sonrasındaki sayımlara bakıldığında Yalova şehri 2007 nüfus sayımında yeniden bir yükselişe geçmiş (87.372) ve 2010 sayımında 100.000 nüfusa çok yaklaşmıştır (98.347). 2013 sayımına göre 104.737 kişi olan Yalova merkezde, 2016'da 137.007 kişi, 2020 yılı verilerine göre ise 149.330 kişi yaşamaktadır (TÜİK, ADNKS 2020), (Şekil 4).

Yalova Merkez ilçeye bağlı köyler ve beldeler ile birlikte Yalova İlçe Merkezinin toplam nüfusu, bulunduğu konum ve avantajlı özelliklerinden dolayı her geçen gün artmaktadır.

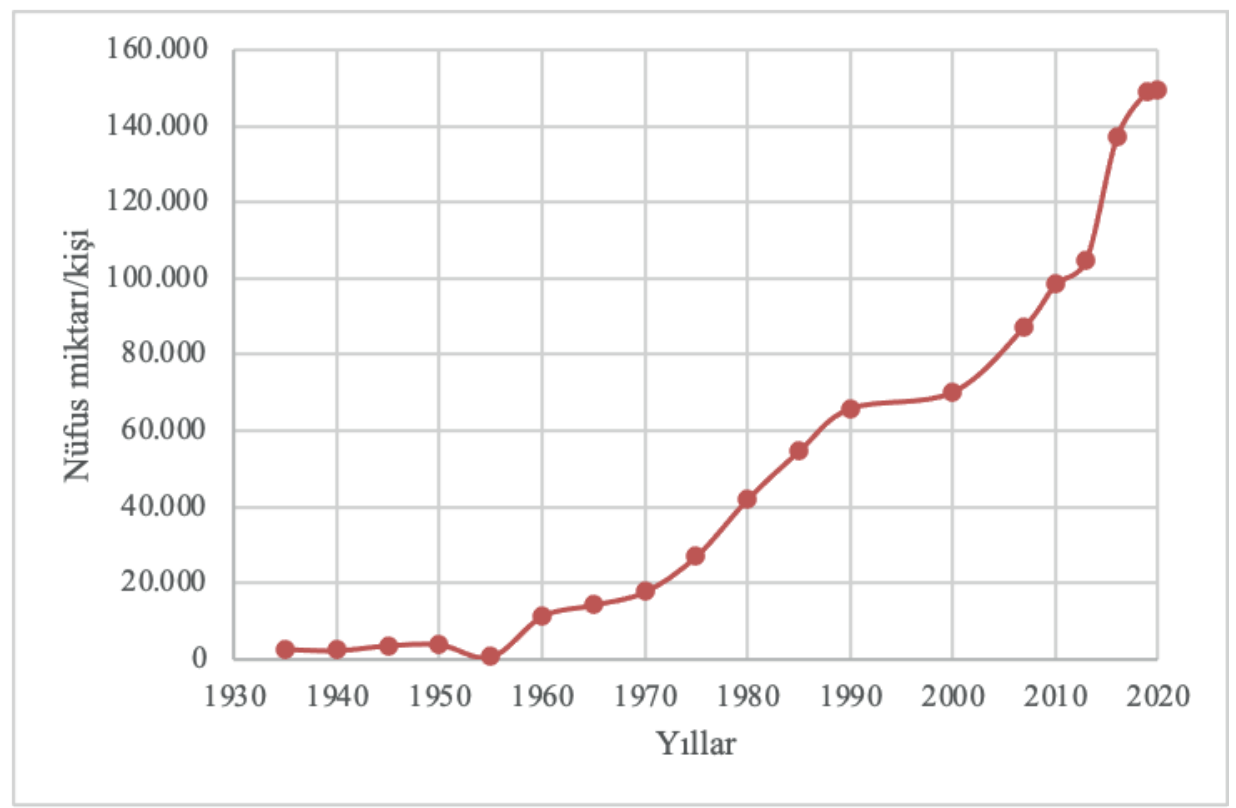

Şekil 4: Yalova Şehrinin Yıllara Göre Nüfus Değişimi.

Figure 4: Population Change Of Yalova City By Year. 
Özellikle şehrin sosyal açıdan ve turizm açısından çekici unsurları ve sahip olduğu avantajları, nüfusu Yalova şehrine çeken unsurları oluşturmaktadır. Buna paralel olarak özellikle turizm açısından yaz dönemlerinde şehir nüfusu artış göstermektedir. Feribotla Yalova'ya yılda ortalama 5,5 milyon yolcu giriş çıkış yapmaktadır. $\mathrm{Bu}$ durum inşaat sektörünün gelişmesine zemin hazırlamıştır. Mevcut nüfusun mahallelere dağılımına bakıldığında Rüstempaşa ve Süleymanbey gibi mahallelerde nüfusun yoğun olduğunu görürüz. Bu mahalleler şehrin merkezinde yer alan ve yaşamsal aktiviteler ile iş olanaklarının yoğunlaştığı alanlardır. Özellikle son ylllarda mahalle özelliği kazanan (Paşakent ve Seyrantepe gibi) mahallelerde nüfus miktarı ve yoğunluğu diğer alanlara göre daha azdır. Yalova şehrinde bulunan 14 mahallenin $\mathrm{km}^{2}$, ye düşen nüfus yoğunluklarında nüfusun büyük bölümünün şehrin merkezi alanları olarak kabul edilen kıyıya yakın olan ve şehrin en eski yerleşim alanlarından olan Bahçelievler, Rüstem Paşa, Süleymanbey gibi mahallelerde yaşadığı görülmektedir (Şekil 5). Rüstem Paşa Mahallesinde nüfus yoğunluğunun fazla olmasının nedeni, kapladığı alanın az, nüfusun fazla olmasıdır. Sayısal verilerden hareketle en az nüfus yoğunluğuna sahip mahallenin ise Paşakent olduğu tespit edilmiştir. Bunun en temel sebepleri ise bu mahallenin kapladığı alan bakımından büyük olması, mahallenin kurulduğu bölgenin büyük oranda imara kapalı olması gösterilebilir. Burada kaçak yapılaşmaya rastlansa da genel olarak imara açık olan yerlerde konutların inşası söz konusudur.

Yalova kıyılarında çok sayıda turizm amaçlı kullanılan 2.konut bulunmakta olup, yazın birçok kişi tatil maksadıyla bölgeye gelmekte, bu dönemde nüfus önemli oranda artmaktadır (Balcı Akova, 2013, s. 75). Ayrıca Yalova şehri sürekli göç alan bir yerleşim yeridir. Yalova'da 2008-2020 yılları arasındaki net göç hızı ortalaması \%o14,32'dir. Nüfusun bir bölümü Karadeniz bölgesinden yapılan göçler ile gelenler ve Balkanlardan göç eden vatandaşlardan oluşsa da, konum olarak merkezi ve yaşam faaliyetlerine elverişli bir yerleşme olmasının da etkisiyle Yalova son yıllarda Türkiye'nin her bölgesinden göç alarak nüfus artışı yaşamıştır. Göç konusundaki azalışta tek istisna 17 Ağustos 1999 Doğu Marmara Depremi ile 2010 yılıdır. Yalova’ya farklı

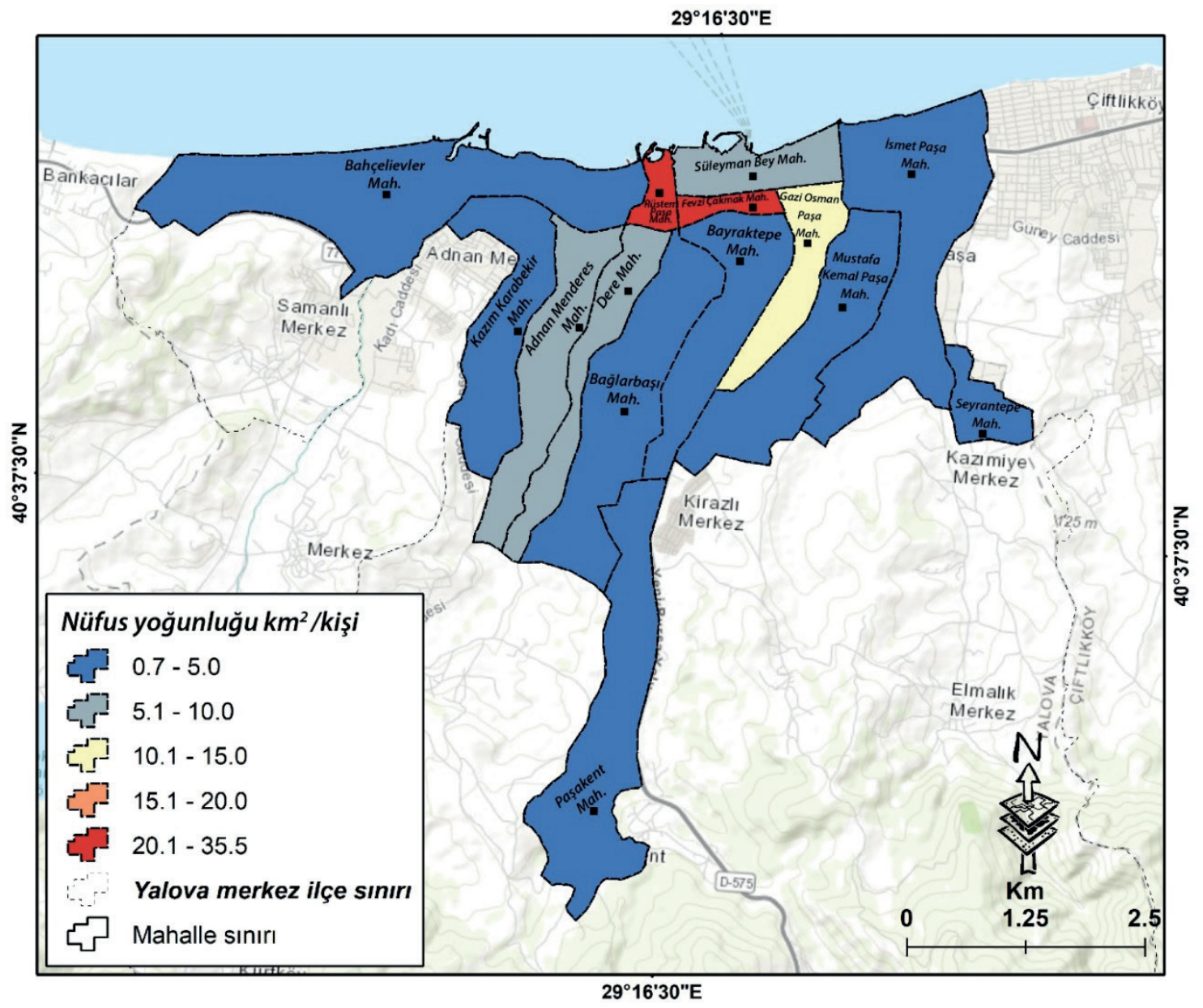

Şekil 5: Yalova Şehrindeki Mahallelerin Ortalama Nüfus Yoğunlukları.

Figure 5: Average Population Densities Of Neighborhoods In Yalova City. 
bölgelerden göçlerin olması ile son yıllarda özellikle Orta Doğudan gelen yabancı uyruklu insanların bölgeye yerleşmesi sonucu farklı gelir düzeyine sahip insanların varlı̆gı, Yalova'nın kültürel bir çeşitlilik kazanmasına yol açmıştır.

\subsection{YALOVA ŞEHIR PLANI VE CADDE-SOKAK SISTEMLERI}

Yalova şehrinin yerleşme alanı çok geniş olmamakla beraber daha çok kıyı alanlarında yoğunlaştığı görülmektedir. Şehri sınırlandıran Samanlı Dağı ve ilçelerin idari sınırları, Yalova şehrinin daha çok Marmara kıyısında yoğunlaşıp kıyıya paralel şekilde toplu bir görünümde olmasına zemin hazırlamıştır. Şehrin kıyılar dâhil olmak üzere yayılma ve yoğunlaşma süreci son yıllarda artarak devam etmekte ve bu durum cadde sokak sistemlerini etkilemektedir.

Kuzeydeki kıyı alanlarında yer alan Bahçelievler Mahallesi, Rüstem Paşa ve Süleymanbey Mahallesinin olduğu alanlara tekabül eden noktalarda yerleşme daha yoğundur. Bunun sebeplerinden birkaçı, bu mahallelerin kıyı şeridinde yer almaları, bölgedeki idari binaların varlığı ve şehrin en eski yerleşme alanlarına tekabül etmeleridir. Bu mahalleler şehrin en önemli yerleşme alanlarıdır. Ancak kıyıdan güneye doğru gidildikçe yerleşmenin seyrekleştiği göze çarpar.

Şehrin batı bölümünde kıyıya paralel uzun caddeler ve bu caddeleri dikine kesen cadde-sokak sistemleri belirgin bir görünümdedir. Şehrin kuzey kıyısı yani Marmara Denizindeki iskele de göze çarpmaktadır. Yalova şehrinde bulunan mahalleler, önemli yol ağları ile birbirine bağlanmış durumdadır. 1.derece yollar, doğuda Çiftlikköy'den şehir ile bağlantıyı sağlayan Atatürk Bulvarı, batıda Termal ve Çınarcık ile Yalova şehrinin bağlantısını sağlayan Termal yolu ve güneyde Bursa yoludur. 2 . ve 3. derece yollar daha çok şehrin içindeki ana arterleri ve caddeleri oluşturmaktadır.

Yalova şehri cadde ve sokak sistemi açısından genel olarak denizin ve yamaçların da konumuna uygun olarak grid bir görünüme yakın bir sistem arzetmektedir. Özellikle şehir merkezinde bulunan ana yol ve cadde aksları ve onu kuzeygüney yönlü kesen sokaklar göze çarpmaktadır (Şekil 6). Bunun
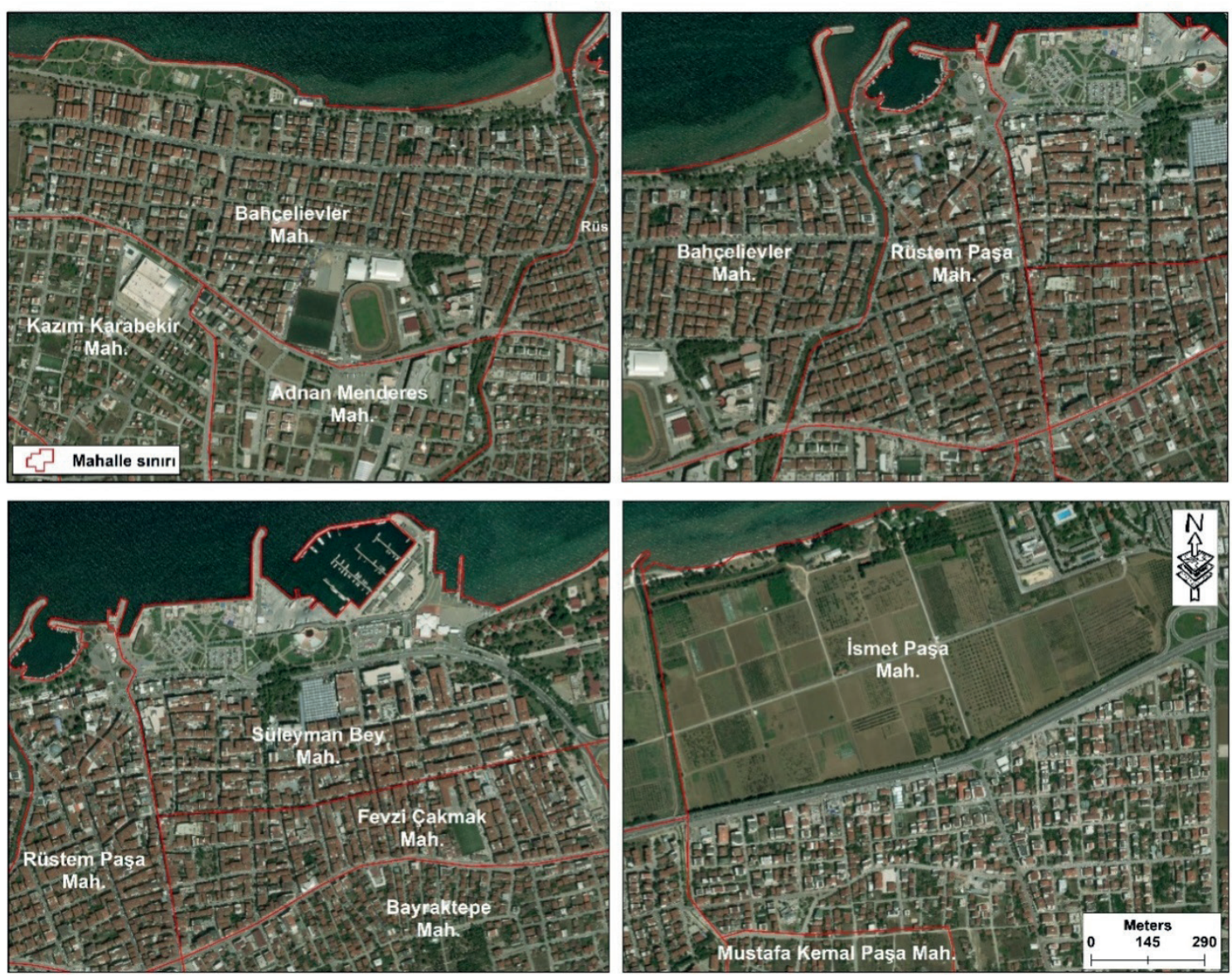

Şekil 6: Yalova Şehri Cadde-Sokakları (ArcGIS 10.5 basemap uydu görüntülerinden faydalanılarak hazırlanmıştır.) Figure 6: The Streets Of Yalova City. 
tek istisnası ise radyal (ışınsal) bir sistem arz eden ve şehrin merkezi olarak adlandırılan, eski hükümet konağının da bulunduğu İskele Meydanı, diğer adıyla Heykel Meydanı adlı bölgede kuzeyden giriş yapan yatay sokaklardır. Bu durum bahsedilen yerde 1şınsal bir sokak sistemi görüntüsüne zemin hazırlamıştır. Esasında klasik Türk şehrinde organik (ivicaçlı) sokak ve cadde sistemi vardır. Yalova'nın bazı kesimleri, Cumhuriyet dönemine kadar buna benzer yapıya sahip olsa da Osmanlının son dönemleri ile Cumhuriyetin kurulmasından sonra cadde ve sokak sisteminde bazı yenilikler meydana gelmiştir. Cumhuriyet döneminde Osmanlı şehirlerindeki merkezi alanlara benzer alternatif yeni merkezler oluşturulmuştur. Bu merkezlerde yeni yönetimin temsil edildiği Hükümet Konağı ile belediye gibi devlet kurumları bulunmaktadır. Merkezden çevreye doğru geniş ve uzun caddelerin bulunduğu 1şınsal bir yol sistemi uygulanmıştır. Yalova'da çıkmaz sokak olarak adlandırılabilecek bir yapıya ise pek rastlanmamaktadır. Cumhuriyetin yeni ve model şehri olarak kurgulanan Yalova, tarihi süreçte bu modele uygun bir görünüme kavuşturulmaya çalışılmıştır.
Yalova şehrinin doğu bölümünde ise özellikle Çiftlikköy ilçe sınırı, şehrin doğudaki sınırını oluşturmaktadır. Çiftlikköy ilçesine yerleşme açısından kademeli bir geçiş söz konusudur. $\mathrm{Bu}$ geçiş, iki yerleşmenin adeta birbirinin devamı olduğu izlenimini vermektedir. Ayrıca Yalova Deresinin şehirdeki yerleşmelere göre olan akışı ve etrafındaki yerleşme dağılışına etkisi gözlenmiştir. Özellikle derenin batı bölümünde yerleşmelerin daha yoğun olduğu söylenebilir. Buranın doğusunda ve güney ucunda yerleşme yoğunluğu diğer alanlara nazaran azdır. Seyrantepe mahallesinde de seyrek yerleşme alanları olduğu söylenebilir. Şehrin doğusunda da nispeten düzgün cadde-sokak yapısı göze çarpmaktadır (Şekil 7).

Şehirde yükseklere çıkıldıkça yamaçların doğrultusuna paralel uzanan, adeta taraça gibi büyük ana üç yol ve cadde aksı bulunmaktadır. Bunların en önemli ikisi, Yalı Caddesi diye adlandırılan ve Armutluya bağlanan yol olarak da bilinen, hastane ve TOKİ evlerinin bulunduğu yoldur. Diğer ana aks ise Bağlar Altı Caddesi diye bilinen Yeşil Çevre Yoludur. Buradaki göze çarpan sokaklardan birisi Ziya Paşa Sokaktır. Hasan Çam
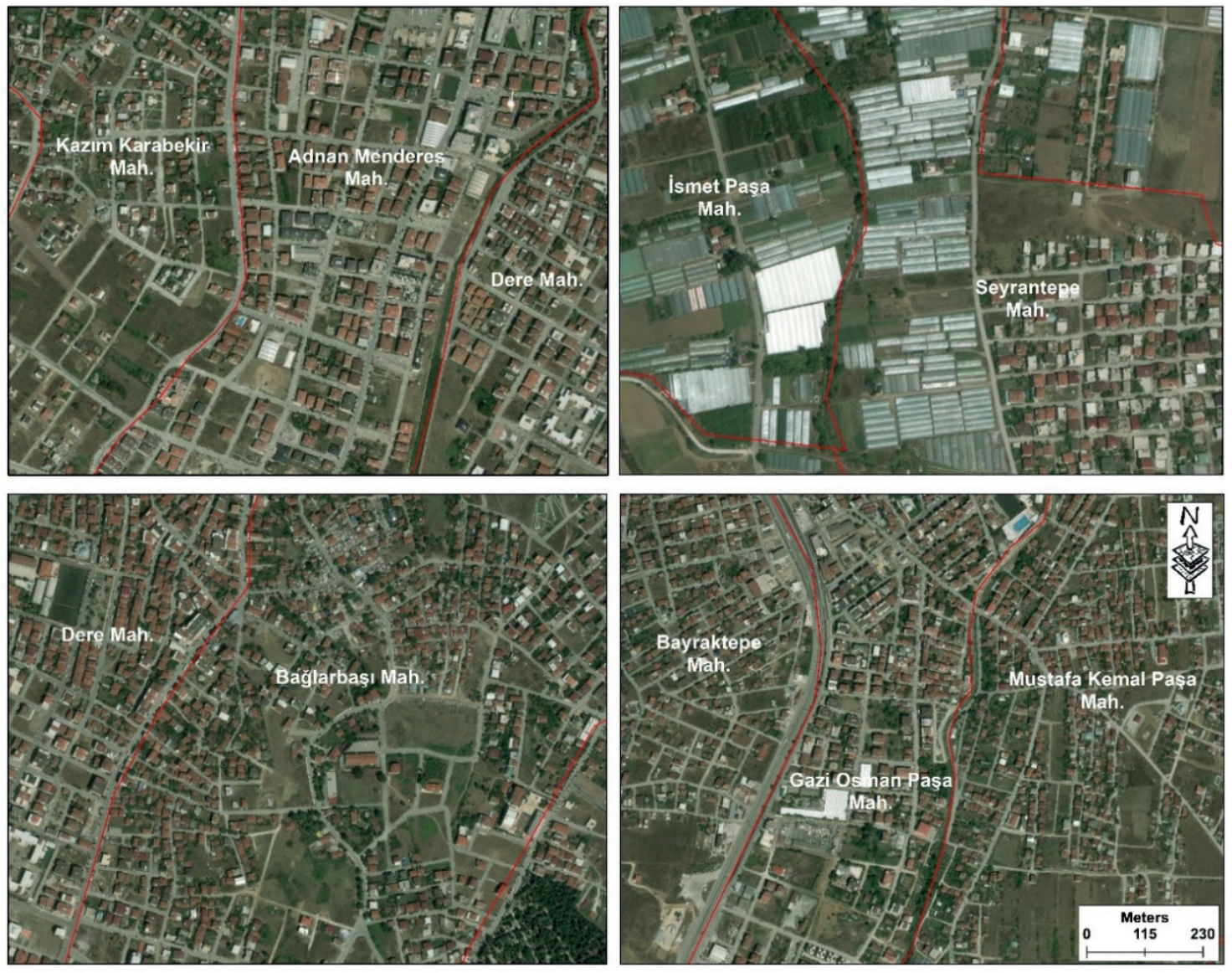

Şekil 7: Yalova Şehri Cadde-Sokakları (ArcGIS 10.5 basemap uydu görüntülerinden faydalanılarak hazırlanmıştır.) Figure 7: The Streets Of Yalova City. 
Caddesi ise kıyıyı dikine kesen caddelerdendir. Bunların yanında şehrin deniz kıyısına yakın olan limanla bağlantılı yürüyüş yolu da mevcuttur. Atatürk Bulvarını takip eden İstanbul Caddesi, Yalı Caddesi, Yaşar Okuyan Bulvarı, Fatih Caddesi, Marmara Denizine paralel olarak şehir merkezinden geçen diğer ana yol akslarıdır. Kadı Caddesi, Rahmi Üstel Caddesi ve Bursa Yalova yolu, güneyden kıyıa dikine inen belirgin yol ve caddelerdir. Aynı doğrultuda şehri paralel kesen, yani liman yoluna doğru şehri dikine kesen Cumhuriyet Caddesi gibi önemli cadde, sokak ve yollar bulunmaktadır. Yamaçlardan denize doğru şehri keserek inen ve yukarı bölümüne Hacımehmet Deresi, kıyıa yakın bölümüne Kocadere (Yalova Deresi) denilen, ayrıca Çiftlikköy ile sınırı oluşturan Safran-Balaban Deresi, Çınarcık yolu gibi ana akslar da bulunmaktadır. Yalova Deresi, şehri Samanlı Dağlarından Marmara Denizine doğru kesen ve şehrin içinde ayrı bir farklılık gösteren, görsellik oluşturan bir karakter sunmaktadır. Dereler dâhil olmak üzere mevcut doğal oluşumlar, şehirde cadde ve sokak yönlerini belirleyen başlıca unsurlar olmuştur. Ayrıca şehrin Çiftlikköy ile bağlantısını Atatürk Bulvarı oluşturmaktadır. Atatürk Bulvarını dikine kesen Balaban Dere ve Yeni Bursa Yolu şehirde göze çarpan unsurlardır. Termal ile olan ana bağlantı ise, Termal Çınarcık yoludur. Şehrin kuzeyinde, yani Marmara Denizine yakın alanlarında Çiftlikköy'den itibaren Yürüyen Köşk, Atatürk Bahçe Kültürleri Merkez Araştırma Enstitüsü, Kapalı Pazaryeri, Liman, Marina alanı, Deprem Anıtı, Öğretmenevi, Atatürk Tarım İşletmesi ve Süs bitkileri sergi alanı göze çarpmaktadır. Şehrin orta kısımlarında Yalova Spor Tesisleri, Hastane, Batı Garajı, Belediye Çamlığı, Huzurevi ve İtfaiye yer almaktadır. Şehrin güney, yani Samanlı Dağlarının eteklerine doğru olan kısımlarında ise, Çömlek Mevkii, Elmalık-Kazımiye köyleri, Bilişim Organize Sanayi Bölgesi, Şehir Mezarlığı, Hayvan Polikliniği, Sanayi Sitesi ve Özel-Devlet okulları mevcut belirgin alanlar olarak görülmektedir.

\subsection{YALOVA ŞEHRINIIN GELIŞSiM YÖNÜ}

Yalova şehrinde en batıda Samanlı Dağları, şehrin hemen batısında bu yöne gelişimin sınırı olan Emir Bayırı, iç bölgesindeki Çamlık Tepe, doğuda Gaziosmanpaşa Mahallesi ve Mandıra Sırtı bulunmaktadır. Bu haliyle şehrin ulaşabileceği sınırlar bellidir. Şehrin özellikle Çiftlikköy sınırı olan doğusu ve Termal sınırı olan batısı, planlamaya fazla müsait değildir. Samanlı Dağları, Emir Bayırı, Marmara Denizi, Çiftlikköy ve Termal ilçe sınırları şehrin gelişimini adeta kontrol etmektedir. Bununla beraber şehir daha çok güneydoğu ve güneybatıya yani Bursa yönüne doğru daha rahat gelişim gösterebilir. Bursa yolundaki deprem dönemine ait prefabrik yapılar, yerini kentsel ölçekle ele alınan yeni yapılaşmalara bırakmaktadır. Bahsedilen bölge, Yalova'nın gelişmiş bir alanı olma yolunda ilerlemektedir. Elmalık Vadi ve Hacı Mehmet Vadi yönleri de gelişime açık alanlar olarak değerlendirilebilir. Ancak bahsi geçen bu bölgelerde son yıllarda açılan imar alanları değerlenmiş ve yer alımı maddi olarak zorlaşmıştır. Bu duruma Üniversiteden dolayı Kadıköy ve Akköy civarı da örnek gösterilebilir. Yalova şehri gelişim durumu bazı planlamalar dâhilinde değerlendirilmektedir. Bunlara örnek olarak aşağıdaki gibi kentsel ölçekli plan gösterilebilir (Şekil 8). Burada şehrin yayıllı̧ ve yoğunluk alanları görülebilir.
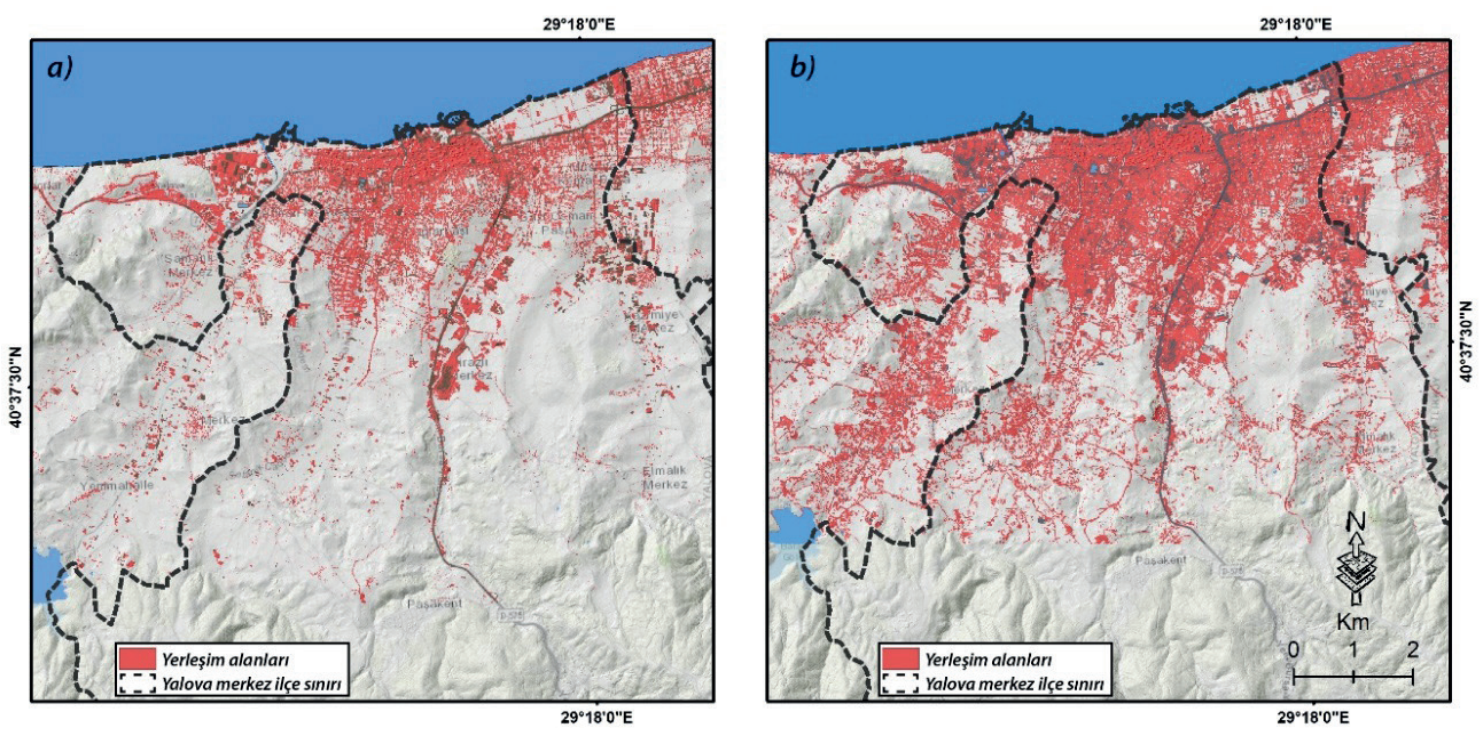

Şekil 8: Yalova şehri a) 2015 b) 2021 yılları arasındaki değişimi (Sentinel-2).

Figure 8: Change of Yalova city from 2015 to 2021. 
Yalova Çevre Düzenleme Planı Raporlarına göre de Yalova şehrinde Kentsel ölçekli planlar toplam 2.375 ha alan kaplamaktadır. Bunun 824 ha'1 mevcut ve öneri konut alanlarından oluşmaktadır. Bu planlarda kentin ana merkezi her yöne bir miktar büyütülerek büyük ölçüde mevcut haliyle korunmuş, bir miktar yoğunluk artışı önerilmiştir. Kent merkezinde alt merkez sayılabilecek merkezi iş bölgeleri yer almamaktadır. Yerleşme alanları kırmızı renklerle çizilmiş olan yukarıdaki Şekil 8'de kuzeydoğuda ve güneybatıdaki 2 noktaya dikkat edilmesi gerekmektedir. Bunlardan ilki kuzeydoğudaki Çiftlikköy sınırı ve diğeri Kadıköy sınırıdır. Bu noktalar mevcut kent merkezinin sürekliliğinin devam ettiği alanlar olmasına rağmen Yalova Belediyesinin hem belediye hem de mücavir alanı dışında (kuzeydoğuda Çiftlikköy, güneybatıda Kadıköy

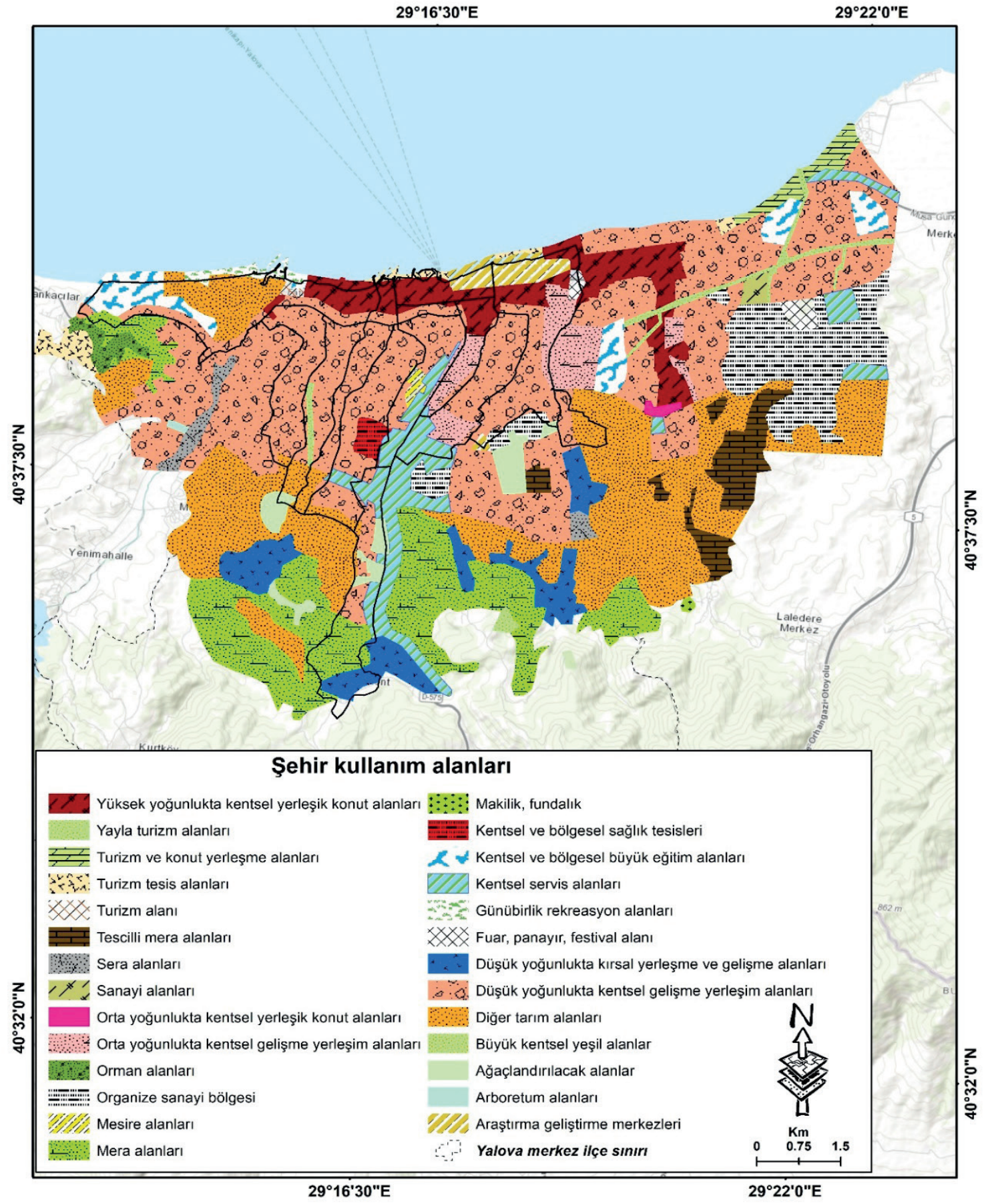

Şekil 9: Yalova Şehri'nin Arazi Kullanım Alanları (1/25.000 ölçekli Yalova Çevre Düzeni planından değiştirilerek hazırlanmıştır.)

Figure 9: Land Use Areas of Yalova City. 
Belediye sınırları) kalmaktadır. İdari sınırlarla ilgili bu özel durum planlama çalışmaları başta olmak üzere her türlü proje kapsamında da ilgili idarelerin işbirliğini zorunlu kılmaktadır. $\mathrm{Bu}$ durum şehrin gelişim yönünü de tayin etmektedir. Sonuç olarak Yalova kentsel ölçekli planların toplam 2.375 ha alan kapladığ 1 ve yaklaşık 200.000 kişinin yer seçebileceği konut alanı kapasitesi olduğu anlaşılmaktadır. Bu planlarda konut alanları toplam 824 ha alana tekabül etmektedir. Bunlardan 527 ha Öneri Konut, 297 ha ise Mevcut Konut alanlarından oluşmaktadır. Bu kapsamda Yalova şehri, yerleşme yoğunluğu bakımından parçalı görüntü formundan ziyade birleşik ve toplu bir yayılma ile gelişeceği tahmin edilmektedir. Bununla birlikte şehirdeki monocentric (tek merkezli) görünümün, Valilik gibi resmi kurumların başka mahalleye taşınması planı ve mahalle meydanlarının gelişmesi ile polycentric (çok merkezli) görünüme kavuşarak ilerleyeceği tahmin edilmektedir.

\subsection{YALOVA ȘEHRININ FONKSIYYON YAPISI}

Bilindiği gibi şehir fonksiyonları, şehir tanımlamalarında ve sınıflandırmalarında önemli bir yeri olan, şehir içinde her biri ayrı bir özellik taşıyan, şehrin önemli hizmet alanlarıdır. $\mathrm{Bu}$ suretle şehir fonksiyonları esas itibariyle şehrin devamlılı̆̆ını sürdürmesinde, gelişmesinde ve çevresiyle sürekli olarak iletişim halinde bulunmasında önemli bir yeri olan, şehirde ve çevresinde bulunan kaynakların doğru bir şekilde kullanılmasını sağlayan, işlevler ve faaliyetler bütünü olup şehirlerin çevrelerine göre merkez olma özelliğini veren faktörlerden biridir (Bayartan, 2002, s. 30-31). Bu kapsamda bakıldığında Yalova şehrinde fonksiyonel olarak hizmetler sektörü ve turizm sektörü öne çıkmaktadır. Ulaşım fonksiyonu açısından da son derece önemli alternatiflere ev sahipliği yapan Yalova, İstanbul-İzmir otoyolu ile Osmangazi Köprüsü sayesinde kritik konuma sahip olmuştur. Ayrıca Marmara Denizi üzerinden birçok il'e ulaşım sağlanmaktadır. Dini, kültürel ve sosyal yaşamın şehir fonksiyonları açısından belirgin etkiye sahip olduğu söylenebilir. Fonksiyonların arazi kullanımına yansıması ise göze çarpmaktadır. Fonksiyonel olarak sanayi alanları ve süs bitkisi yetiştirme alanları görülmektedir. Şehir alanının daha çok yerleşmeye ayrıldığı söylenebilir. Fonksiyonel alan dağılımının da fark edildiği aşağıdaki Şekil 9'da, mevcut kullanım alanı özelliklerinin büyük ölçüde, kuzeybatı ve kuzeydoğuda sahile yakın kesimlerdeki mülkiyeti kamuya ait alanlar ile Bursa yolunun genel olarak doğusunda kalan alanlarda Bilişim Organize Sanayi Bölgesi, Fuar alanı, Küçük Sanayi Siteleri, Araştırma Geliştirme Alanları vb. çalışma alanı kullanışları yer almaktadır. Kuzeybatıda turizm amaçlı bir bölüm, üniversite kampüsü, spor kompleksi, önerilen ve mevcut önemli kullanım alanları olarak karşımıza çıkmaktadır. Şehrin orta kısımları ise genel olarak yerleşmeye ayrılmış durumdadır. Şehirde eğitim fonksiyonu açısından bakıldığında temel eğitim, ortaöğretim ve yaygın eğitim imkânları yeterli görülmekte ve bu da okuryazar oranı ile diğer eğitim parametrelerine olumlu yansımaktadır. Ayrıca son yıllarda şehirdeki üniversitenin işlerlik kazanması ile eğitim açısından ayrı bir canlılık ve katma değer ortaya çıkmaktadır.

Şehrin doğu kıyılarında Araştırma Enstitüsünün geniş bir alan kapladığı görülmektedir. Şehrin en güneyinde sanayi sitesi mevcuttur. Şehrin orta kıyı bölümünde özellikle limana yakın sahil hattında park alanları geniş yer kaplamaktadır. Yine orta kıyı bölümlerinde ticaret alanları göze çarpmaktadır. Şehrin en batısında TİGEM (çiçek) arazisi geniş alan kaplamaktadır. Dini tesisler ve eğitim kurumları, şehrin muhtelif kesimlerinde yerleşme yoğunluğuna göre dağılmıştır. Konut alanları daha çok şehrin orta bölümlerinde yaygınken, gelişmekte olan konut alanları daha çok şehrin güneydoğu ve güneybatı kesimlerinde yaygındır. Kıyı alanlarına paralel olarak konut-ticaret alanları yoğunluktadır. Resmi kurumlar daha çok şehrin kıyılarındaki eski yerleşim alanlarında yoğundur. Ancak idari merkezlerin şehrin biraz dışına taşınması ve taşındığı merkezde kapalı otopark ile meydan yapılma çalışmaları başlatılmıştır. Şehir içinde sayılabilecek bazı alanlarda çiçek tarımı için ayrılan araziler de görülebilmektedir.

\section{TARTIŞMA VE SONUÇ}

Yalova şehri büyük şehir merkezlerine yakın ve daima göz önünde bulunan bir konumda olmasına karşın, şehirsel özellikleri ve potansiyeliyle alakalı çok fazla araştırma yapılmamıştır. $\mathrm{Bu}$ yaklaşım çerçevesinde şehir tüm yönleriyle araştırılmıştır. Yalova'da ekonomik hayat, sanayi sektöründe tekstil, kimya, kâğıt gibi alanlar, hizmetler sektörü içinde ise kamu-özel sektörlerindeki iş kolları ve turizm kollarına dayanmaktadır. Bununla beraber Yalova, önemli bir seracilık ticaret ve pazarlama merkezi haline gelmiştir. Buna zemin hazırlayan unsurlara örnek olarak Yalova'nın önemli metropoller ile büyük pazarlara yakın olması, alternatif ulaşım potansiyeli, iklim koşullarının uygunluğu ve Yalova Atatürk Bahçe Kültürleri Merkez Araştırma Enstitüsü tarafından hayata geçirilen çiçek kalitesini artırmak gibi faktörler gösterilebilir. Ayrıca çiçek üretim miktarı ile ürün kalitesinin istenilen seviyede olması, ayrıca çiçek üreticilerinin yeterli teknik donanıma sahip olması da önemli faktörlerdir. Üretimi yapılan ürünler, Yalova şehri ile ticari açıdan ilişkilidir. Yalova sınırları, günümüzde tam teşekküllü bir havayolu ulaşımı imkânına sahip değildir. Ancak Hava Harp Okulu'na ait, Yalova-Kocaeli karayolu 
üzerinde küçük bir havaalanı bulunmaktadır. Bu havaalanı sadece askeri anlamda değil, aynı zamanda kesme çiçek taşımacılığı için de kullanılabilecek potansiyele eriştirilebilirse ticari katma değer sağlayacaktır. Ekonomik açıdan şehir halkının en önemli sorunlarından birisi istihdam problemidir.

Yalova şehrinde, konut ve donatı alanlarına yürüme mesafesinde kolayca erişilebilirlik sağlandığı görülmektedir. Şehirde, belirli dönemlerde alınan kararlar ile sahil bandında yayalaştırma alanları oluşturulmuştur. Bu alanlar ekonomik açıdan canlılık arz eden, şehrin sosyal donatı alanlarına tekabül etmektedir. Bu itibarla bahsi geçen alanların kıyı kanunlarına göre korunması önemlidir. Şehirde cadde sokak sistemlerinin düzenli bir görünüme sahip olması, yaşam konforu açısından avantajdır. Şehrin yayılması için öngörülen öneri konut alanlarında da düzenli ve ferah bir mimari kullanılması yaşam konforu açısından önemlidir. Ancak bu yayılmalarda coğrafi şartların göz önüne alınması ve çevreyle uyumlu hareket edilmesi sağlanmalıdır.

Özellikle Bithynia, Roma-Bizans ve Osmanlı dönemlerinde Yalova Kaplıcaları, bölgede yerleşmelere zemin hazırlayan ve daha sonra şehrin kuruluşunu etkileyen en önemli olgudur. Yerleşme, sağlık turizmi açısından tarihinin her döneminde önemini artırarak devam ettirmiştir. Şehrin ulaşılabilirlik açısından pratik alternatifler sunması, diğer yerleşmelerle bağını güçlendirmektedir. Örneğin Şehrin Marmara Denizine kıyısı olması, deniz ulaşımı açısından artı bir değer katmaktadır. Özellikle İstanbul-Yalova ulaşılabilirliğinin Deniz Otobüsleri ve Körfez Geçiş Köprüsü (Osmangazi Köprüsü) vasıtasıyla kolay ve kısa olması, insanların şehir hayatından kopmadan diğer şehre geçmelerini sağlamakta ve bu geçişin şehir hayatının bir devamı olduğunun hissedilmesine zemin hazırlamaktadır. Şehir, çevresiyle bir bütündür. Bu açıdan Yalova, şehir kültüründe yakınındaki diğer yerleşmelerle tamamlayıcı özelliklere sahiptir. Balkan göçmenlerinin şehre gelişi ve Türkiye'nin birçok yöresinden çeşitli zamanlarda Yalova şehrine yapılan göçler, şehirde kültürel bir çeşitliliğe ve zenginliğe de yol açmıştır. Farklı folklorik unsurların bir arada yer alması, şehre ayrı bir canlılık katmaktadır.

Yerleşme açısından Yalova şehri uygun koşullar sunmaktadır. Kıyı şehri olması ile arazi şartları gibi diğer coğrafi şartların uygun olması, yerleşme durumu ve çevresindeki tarımı olumlu yönde etkilemektedir. Ancak yerleşme özellikleri açısından şehrin büyüme alanları belli ve sınırlıdır. Samanlı Dağları, Marmara Denizi ve diğer ilçe sınırları Yalova şehrinde yerleşmenin çok dağınık olmasını önlemiş ve daha kontrollü bir yayılma planı izlenmiştir. Şehrin yayılma alanlarında tarım alanı olabilecek verimli sahaların konut yapımına ayrılması uzun vadede bir sorun olarak görülebilir.

1995 yılında idari olarak İstanbul'dan ayrılıp ayrı bir il olan Yalova'da yerleşme ve nüfus dengeli bir artış göstermektedir. Özellikle 1999 Marmara Depremi sonrası şehirdeki nüfus artış hızında meydana gelen bir miktar azalma, sonrasında yerini kademeli olarak artışa bırakmıştır. Bununla birlikte Yalova yazlık kent olarak görüldüğü için, sezonlar arası nüfus oldukça farklıdır. Mevsimsel göç (iç turizm ve işgücü) kaynaklı değişken nüfusun şehrin mevcut dokusunu gerek şehircilik gerekse sosyal açıdan değiştirdiği gözlemlenmektedir. Ayrıca Arap turistlerin bölgeye olan ilgisiyle birçok sektör gelişim kat etmiştir.

Yalova şehri depremsellik açısından riskli bir konumdadır. Bundan dolayı önceki depremler ve sonuçlarından da yola çııılarak, özellikle konut yapımında zemin etütleriyle birlikte sağlamlık ön plana çıkmalı, bu noktada denetimler yoğunlaştırılmalıdır. Şehrin bulunduğu zeminin büyük oranda alüvyal dolgu olması gerçeğinden hareketle, bahsi geçen kontroller ve uygulamalar, olası bir deprem tehlikesinden dolayı hayati önem taşımaktadır. Bu kapsamda son yıllarda devlet eliyle yapılan çalışmalara hız verilmelidir.

Yalova şehri merkezi konumu ve çekici doğal unsurlara olan yakınlığıyla, tam bir turizm merkezi olma hüviyetine sahiptir. Yalova'nın büyük şehirlere olan yakınlığı, turizmde erişilebilirlik açısından önemlidir. Bu kapsamda insanları Yalova'ya çekecek tanıtım faaliyetlerinin yoğunlaştırılması gerekmektedir. Yalova'da ayrıca süs bitkileri yetiştiriciliğindeki potansiyelin değerlendirilmesi ekonomik olarak gelecekte belirleyici olacaktır. Ayrıca şehirde bulunan üniversite ile eğitim açısından ayrı bir canlılık ve katma değer ortaya çıkmaktadır. Sonuç olarak Yalova şehri, ticaret, yerleşme ve turizm açısından insanlara müreffeh imkânlar sunma potansiyeline sahip önemli bir yerleşme alanıdır.

\footnotetext{
Bilgilendirilmiş Onam: Katılımcılardan bilgilendirilmiş onam alınmıştır. Hakem Değerlendirmesi: Dıș bağımsız.

Yazar Katkıları: Çalışma Konsepti/Tasarım- E.K., M.B.; Veri Toplama- E.K.; Veri Analizi/ Yorumlama- E.K.; Yazı Taslağı- E.K.; İçeriğin Eleştirel İncelemesi- E.K., M.B.; Son Onay ve Sorumluluk- E.K., M.B.

Çıkar Çatışması: Yazarlar çıkar çatışması bildirmemiştir.

Finansal Destek: Yazarlar bu çalışma için finansal destek almadığını beyan etmiştir.

Informed Consent: Written consent was obtained from the participants.

Peer-review: Externally peer-reviewed.

Author Contributions: Conception/Design of Study- E.K., M.B.; Data Acquisition- E.K.; Data Analysis/Interpretation- E.K.; Drafting Manuscript- E.K.; Critical Revision of Manuscript- E.K., M.B.; Final Approval and Accountability- E.K., M.B.

Conflict of Interest: The authors have no conflict of interest to declare.

Grant Support: The authors declared that this study has received no financial support.
} 


\section{KAYNAKÇA/REFERENCES}

Ahmed, R., (Altınay), (1930). Hicrî On ikinci Asırda Ístanbul Hayatı (1100-1200), İstanbul, Devlet Matbaas1, İstanbul.

Akova, İ., (2013). Sürdürülebilir Turizm, Prof. Dr. Süha Göney'e Armağan (Ed:Mehmet. Bayartan). İstanbul Üniversitesi Yayını, s.107-136, İstanbul.

Aliağaoğlu, A., Uğur, A. (2021). Şehir Coğrafyası, (8.Baskl), Nobel Akademik Yayınc1lık, Ankara.

Balcı Akova, S. (2013). Yalova'da Kırsal Alanlarda Kalkınma Imkanları ve Sürdürebilirlik, Prof. Dr. Süha Göney'e Armağan (Ed: Mehmet Bayartan). İstanbul Üniversitesi Yayını, s. 51-106, İstanbul.

Bayartan, M. (2002). "Kentsel Fonksiyonların Ortaya Konmasinda ve Değerlendirilmesinde Coğrafi Bilgi Sistemlerinin Kullanımı”, 3031 Ekim 2002 Fatih Üniversitesi Coğrafi Bilgi Sistemleri Bilişim Günleri, s. 1-12, İstanbul.

Bayartan, M. (2010). İnsan-Zaman-Mekân Bağlamında Şehirler, 1. Milletlerarası Şehir Tarihi Yazarları Kongresi, 5-7 Kasım 2010, Türkiye Yazarlar Birliği Yayınları, s. 228-233. Ankara.

Ceylan, M. A. (2003). Marmara Depreminin (17 Ağustos 1999) Yalova Şehrine Etkileri, Gündüz Eğitim ve Yayıncılık, Ankara.

Ceylan, M. A. (2000). Ulaşım Coğrafyası Açısından Eskihisar-Topçular Deniz Ulaşımı, Marmara Denizi 2000 Sempozyumu Bildiriler Kitabı (Ed. Bayram Öztürk-Mikdat Kadıŏlu-Hüseyin Öztürk), s.189-197, İstanbul.

Doğanay H. (1994). Türkiye Beşeri Coğrafyası, Gazi Büro Kitapevi, Ankara.

Evliya, Çelebi, (1970). Evliya Çelebi Seyahatnamesi, (Çev. Zuhuri Danışman), İstanbul.
Kazel, E. (2014). Yalova Şehir Coğrafyası (Yüksek Lisans Tezi), İstanbul Üniversitesi Sosyal Bilimler Enstitüsü, İstanbul.

Göney, S. (2017). Şehir Coğrafyast, Cilt 1 (Ed:Mehmet. Bayartan), Beta Yayınc1l1k, İstanbul.

Göney, S. (2017). Şehir Coğrafyası, Cilt 2 (Ed:Mehmet. Bayartan), Beta Yayınc1lık, İstanbul.

Kollektif, (2005). Işste Yalova, Marpar Marmara Piyasa Araştırma Merkezi Ltd. Şti. Yayınları, Yalova.

Mansel, A. M. (1950). Yalova ve Civarı, Belediyeler Y1llığı Basımı, 713, Ankara.

Mansel, A. M. (1936). Yalova ve Civarı (Yalova UndÜmgeBung), İstanbul Müzeleri Neşriyatı, İstanbul.

Tanoğlu, A. (1966). Nüfus ve Yerleşme, İstanbul Üniversitesi Yayınları, İstanbul.

Taner, N. (1996). Yalova'da Milli Mücadele Günlüğü 1920-1922, İstanbul.

Taner, N. (1984). Her Yönüyle Yalova, İstanbul.

Tuncel, M. (2013). Yalova, İslam Ansiklopedisi, Türkiye Diyanet Vakfi Basım1, cilt: 43, s. 306-308, İstanbul.

Tümertekin, E. (1980). İstanbul'da Nüfus Dăğllı̧ıı. İstanbul Üniversitesi Coğrafya Enstitüsü Yayını, İstanbul.

Uğur, A., Aliağaoğlu, A. (2020). Şehir coğrafyası: Türkiye'de Şehir Coğrafyasının Gelişimi. Doğu Coğrafya Dergisi, 25(44), 46-60.

İbret, B. Ü. (2004). Tosya Şehrinin Fonksiyonel Özellikleri. Marmara Coğrafya Dergisi, 9, 49-88.

*Modül Planlama ve Yalova Belediyesi Sayısal Verileri.

*http://www.yalova.bel.tr/Content/images/Yalova\%20Uygulama\%20

$\% \mathrm{C} 4 \% \mathrm{~B} 0 \mathrm{mar} \% 20 \mathrm{Plan} \% \mathrm{C} 4 \% \mathrm{~B} 1 . \mathrm{pdf}$ 